\title{
Reproductive Development of Lotus tenuis (Fabaceae) Crop Defoliated at Different Times and Intensities
}

\author{
Osvaldo R. Vignolio, Gustavo S. Cambareri, Lucas R. Petigrosso, \\ Natalia Murillo, Néstor O. Maceira \\ Facultad de Ciencias Agrarias, Universidad Nacional de Mar del Plata-Estación Experimental Agropecuaria \\ Balcarce, Instituto Nacional de Tecnología Agropecuaria, Balcarce, Argentina \\ Email: vignolio.osvaldo@inta.gob.ar
}

Received 21 March 2016; accepted 4 June 2016; published 7 June 2016

Copyright (C) 2016 by authors and Scientific Research Publishing Inc. This work is licensed under the Creative Commons Attribution International License (CC BY). http://creativecommons.org/licenses/by/4.0/

(c) (i) Open Access

\section{Abstract}

Lotus tenuis forage yield has been quantified under defoliation conditions in pastures, grasslands and under dual-purpose production of both livestock forage and seeds. However, little is known about the effects of defoliation management on $L$. tenuis flower and pod production and subsequent seed yield. Two field experiments were conducted to study the response of $L$. tenuis to defoliation at different flowering stages and intensities. In Experiment 1, crops were defoliated at the beginning of the flowering (DBF), mid-flowering (DMF) or full flowering (DFF). In Experiment 2, defoliation was in vegetative stage at low (LDI) or high (HDI) intensities. Defoliation in Experiment 1 neither affected plant cover nor the photosynthetically active radiation intercepted by the crop during pod production. There were less umbels with dehiscent (shattered) pods in the DFF treatment than in Control, DBF and DMF treatments. Flower peak occurred first in the Control, DBF and DMF treatments, and eight days later in DFF plots, however, seed yield was not affected (1324 \pm $\left.32.8 \mathrm{~kg} \cdot \mathrm{ha}^{-1}\right)$. Defoliation intensity did not affect seed yield $\left(962 \pm 25.9 \mathrm{~kg} \cdot \mathrm{ha}^{-1}\right)$ because of self-compensation which increased harvest index in HDI $(14.5 \% \pm 0.6 \%)$ compared to the Control and LDI $(12.0 \% \pm 0.3 \%)$ treatments. Plant survival was not affected by defoliation treatments in any of the experiments. Flowering can be synchronized through defoliation. The blooming of large numbers of flowers in a short time was achieved, reducing the number of shattered pods. Compensatory responses through plant plasticity conferred $L$. tenuis the ability to overcome defoliation without affecting seed yield. Lotus tenuis defoliation as management tool will be considered in future researches because it is possible to harvest forage and to increase seed yield through a reduction of shattered pods. 


\section{Keywords}

\section{Cutting, Narrowleaf Birdsfoot Trefoil, Vegetative Biomass, Flowering Time, Yield}

\section{Introduction}

Lotus tenuis is a forage legume native of the Mediterranean region. It has been investigate as a potential forage for grazing ruminal in New Zealand, USA, Australia and South America [1]-[6]. The management of this species has been quantified under defoliation conditions in pastures, grasslands and under dual-purpose production of both livestock forage and seeds [7]. However, little is known about the effects of defoliation management on L. tenuis flower and pod production and subsequent seed yield [8] [9].

Lotus tenuis presents a number of agronomic and economic benefits such as a) atmospheric nitrogen biological fixation, b) increase in biomass production and quality of pastures and grasslands, c) rise in beef cattle productivity through improving animal performance, d) contribution in honey production and e) low farming input requirements as nitrogen and phosphorus fertilizers [2] [3] [10]-[12].

Crop vegetative biomass production and seed yield can be modified through frequency and intensity of defoliation at different phenological stages [2] [8] [9] [13]-[15]. Seed yield losses are lower when shoot biomass is removed during the vegetative stage, in comparison to the reproductive phase, because the plants are able to reestablish their canopies and photosynthetic capacity [16]. Flowering can be synchronized through defoliation and the blooming of large numbers of flowers in a short time provides a uniform seed ripening [8] [9]. In contrast, defoliation at early flowering in different forage legumes such as Lotus pedunculatus, L. corniculatus and Trifolium spp. can delay the onset of flowering, reduce pod number, seeds per pod and, consequently, seed yield [17] [18].

The objective of this study was to investigate the response of reproductive development and yield of Lotus tenuis to defoliation applied at different phenological stages and intensities and its ability for compensating the cutting effects.

\section{Materials and Methods}

\subsection{Experimental Site}

Two experiments were carried out at the Unidad Integrada Balcarce (Estación Experimental Agropecuaria, Instituto Nacional de Tecnología Agropecuaria Balcarce-Facultad de Ciencias Agrarias, UNMdP, Buenos Aires, Argentina; $37^{\circ} 45^{\prime} \mathrm{S}, 58^{\circ} 18^{\prime} \mathrm{W}, 130 \mathrm{~m}$ above sea level). The experiments 1 and 2 were performed in the years 2010-2011 and 2011-2012, respectively. The soil was a well-drained Typic Argiudoll [19] and analyses tests on the upper soil $15 \mathrm{~cm}$ indicated, average \pm SEM of boths experiments, with $\mathrm{pH}$ of (ratio soil: $\mathrm{H}_{2} \mathrm{O}, 1: 2.5$ ) $6.6 \pm 0.2$, organic matter content of $5.9 \% \pm 0.3 \%$, phosphorus content (by the Bray 1 method) $28.1 \pm 3.3 \mathrm{mg} \cdot \mathrm{g}^{-1}$ and $\mathrm{NO}_{3}-\mathrm{N}$ of $33.3 \pm 8.0 \mathrm{mg} \cdot \mathrm{g}^{-1}$. The climate is temperate, humid-subhumid with annual precipitation of $951 \mathrm{~mm}$ (1992-2012) and an annual average air temperature of $14.2^{\circ} \mathrm{C}$, ranging from $3.2^{\circ} \mathrm{C}$ in July to $28^{\circ} \mathrm{C}$ in January. The growing season is particularly dry during the seed filling period of summer crops. A weather station of the Unidad Integrada Balcarce recorded rainfall $(\mathrm{mm})$, maximum and minimum air temperature $\left({ }^{\circ} \mathrm{C}\right)$, solar radiation $\left(\mathrm{MJ} \cdot \mathrm{m}^{-2} \cdot \mathrm{d}^{-1}\right)$, reference evapotranspiration $(\mathrm{mm})$ each day during the experiment (Table 1$)$.

\subsection{Plant Material and Defoliation Treatments}

Lotus tenuis seed cv. Pampa INTA (0.974 \pm 0.006 g thousand seed weight), was used in both experiments [9]. In winter, the experimental field was prepared to produce a fine seedbed for Experiments 1 (sown 2010) and 2 (sown 2011). Plant density was 20 plants $\cdot \mathrm{m}^{-2}$, consistent with maximum seed yield of L. tenuis [9]. To control plant density, plants were manually transplanted. Plants were obtained from seeds, scarified with sand paper to break physical dormancy, inoculated with Rhizobium loti $\left(\mathrm{N}_{2}\right.$-fixing strain 733$)$ and sown into pots of $35 \mathrm{~cm}^{3}$ in winter [9]. Plants were transplanted on October 20, 2010 for Experiment 1 and on October 11, 2011 for Experiment 2. Total biomass (stems, leaves and roots) of transplanted plants was $84.2 \pm 5.7 \mathrm{mg} \cdot \mathrm{plant}^{-1}$ and $104 \pm 8.9$ mg.plant ${ }^{-1}$ for Experiment 1 and 2, respectively. In both experiments, Lotus tenuis plants were arranged in 8 
Table 1. Accumulated irrigation, rainfall and evapotranspiration (ETP), total water (irrigation plus rainfall) and monthly means of maximum (Max.) and minimum (Min.), air temperature and daily solar radiation. Data were provided by the Unidad Integrada Balcarce meteorological station.

\begin{tabular}{|c|c|c|c|c|c|c|c|}
\hline \multirow{2}{*}{ Year/Months } & \multirow{2}{*}{$\begin{array}{l}\text { Irrigation } \\
(\mathrm{mm})\end{array}$} & \multirow{2}{*}{$\begin{array}{c}\text { Rainfall } \\
(\mathrm{mm})\end{array}$} & \multirow{2}{*}{$\begin{array}{l}\text { ETP } \\
(\mathrm{mm})\end{array}$} & \multirow{2}{*}{$\begin{array}{l}\text { Total water } \\
\text { (mm) }\end{array}$} & \multirow{2}{*}{$\begin{array}{l}\text { Solar radiation } \\
\left(\mathrm{MJ} \cdot \mathrm{m}^{-2} \cdot \text { day }^{-1}\right)\end{array}$} & \multicolumn{2}{|c|}{ Temperature } \\
\hline & & & & & & $\operatorname{Max} .\left({ }^{\circ} \mathrm{C}\right)$ & $\operatorname{Min} .\left({ }^{\circ} \mathrm{C}\right)$ \\
\hline \multicolumn{8}{|c|}{ Experiment 1} \\
\hline \multicolumn{8}{|l|}{2010} \\
\hline October & 38.4 & 44.7 & 92.0 & 83.1 & 15.4 & 19.3 & 7.7 \\
\hline November & 38.4 & 115.8 & 119.5 & 154.2 & 20.9 & 22.7 & 9.7 \\
\hline December & 83.3 & 33.3 & 174.8 & 116.6 & 25.0 & 28.6 & 13.1 \\
\hline \multicolumn{8}{|l|}{2011} \\
\hline January & 39.1 & 185.2 & 159.2 & 224.3 & 22.8 & 28.7 & 15.8 \\
\hline February & 37.8 & 32.6 & 116.2 & 70.4 & 20.4 & 26.0 & 14.2 \\
\hline \multicolumn{8}{|c|}{ Experiment 2} \\
\hline \multicolumn{8}{|l|}{2011} \\
\hline October & 35.0 & 40.9 & 91.3 & 75.9 & 15.5 & 18.5 & 7.5 \\
\hline November & 44.4 & 150.9 & 133.5 & 195.3 & 20.3 & 21.2 & 12.3 \\
\hline December & 74.2 & 35.8 & 152.1 & 110.0 & 22.7 & 26.5 & 13.1 \\
\hline \multicolumn{8}{|l|}{2012} \\
\hline January & 85.9 & 58.3 & 171.2 & 144.2 & 22.9 & 30.8 & 15.5 \\
\hline February & 85.0 & 102.9 & 134.8 & 187.9 & 19.6 & 29.3 & 17.6 \\
\hline
\end{tabular}

rows with spacing of $0.175 \mathrm{~m}$ in plots of $4.00 \mathrm{~m} \times 1.25 \mathrm{~m}$. Two rows of plants were left around each plot to prevent border effects. Plots were separated by paths $0.60 \mathrm{~m}$ wide. Plant density was $20 \mathrm{pl} \cdot \mathrm{m}^{-2}$, recommended value for L. tenuis seed production [9]. Figure 1 summarizes the measurements for each Experiment, $L$. tenuis growth period, plant phenology, defoliation treatments and crop harvest at the end of the Experiments.

Defoliation in Experiment 1 was at the beginning of the flowering (DBF), mid-flowering (DMF) or full flowering (DFF). Control plots were not defoliated during the course of experiment. Defoliation criteria was to reduce crop height by approximately $40 \%$ compared with pre-defoliation crop height (Table 2) either before flowering (DBF), at mid-flowering (DMF) or at full flowering (DFF). In Experiment 2, at the vegetative phase two defoliation intensities were applied, low (LDI) crop height reduced by 54\% compared to pre-defoliation crop height and high (HDI), crop height reduced by 75\% (Table 3). Both experiments had a design complete randomized block with four and five replicates for the treatments of the experiments 1 and 2, respectively.

In both experiments plots were clipped using hand shears. The aboveground dry matter (DM) was harvested from $1 \mathrm{~m}^{2}$ area (1.45 m long $\times 0.70 \mathrm{~m}$ wide). Dry weight was determined after drying at $60^{\circ} \mathrm{C}$ to constant weight (Table 2 and Table 3). Figure 1 summarizes the measurements for each Experiment, $L$. tenuis growth period, plant phenology, defoliation treatments and crop harvest at the end of the Experiments.

Experiments were hand weeded without modifying the crop architecture and vegetation cover. All treatments were irrigated two or three times per week. The criteria were based on irrigation plus rainfall which replaced evapotranspiration (Table 1). The flowers were pollinated by honey bees (Apis mellifera L.), from hives placed approximately $500 \mathrm{~m}$ from the experimental field. Symptoms of water stress, pests and herbivores attacks were not detected.

\subsection{Crop Cover}

Crop cover was determined immediately before defoliation (Table 1 and Table 2). A Panasonic Lumix (Model 

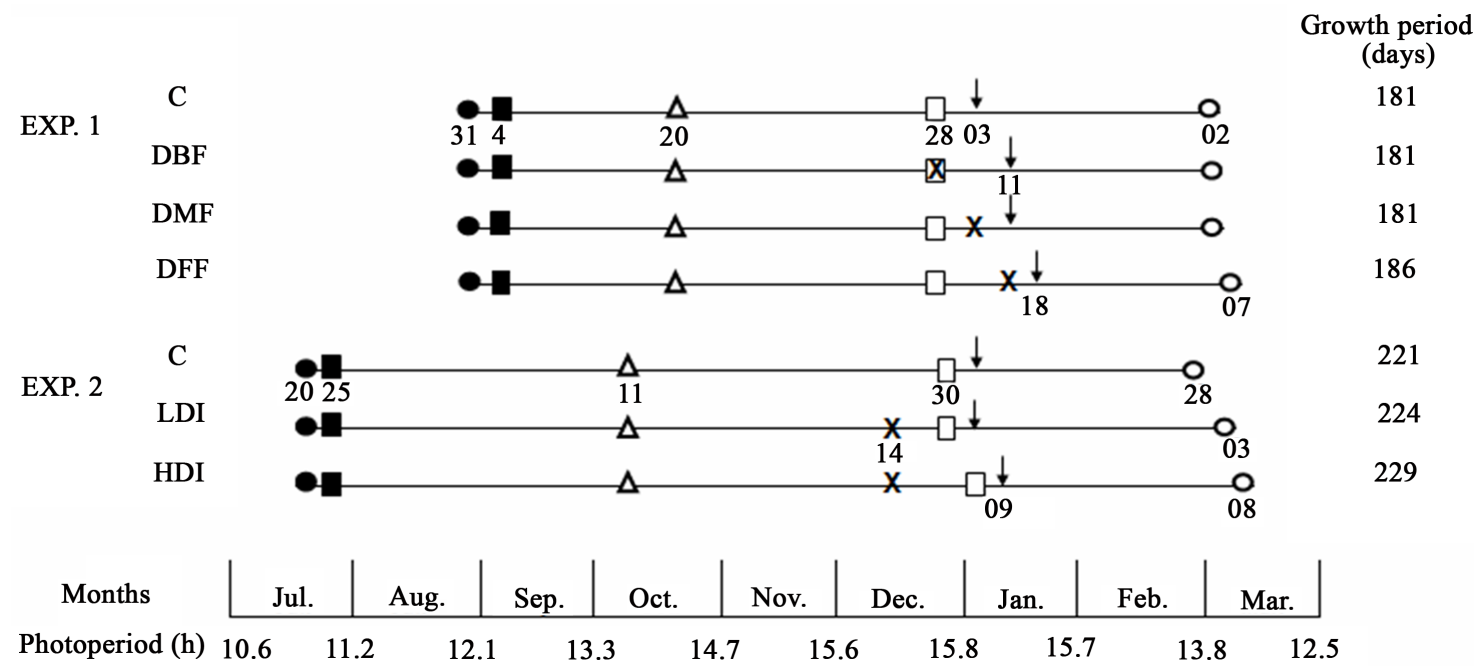

Figure 1. Schedule of Lotus tenuis growth period and treatments in the Experiments 1 and 2. Abbreviations are: Experiment (Exp.), Control (C), defoliation at the beginning of the flowering (DBF), mid-flowering (DMF) and full flowering (DFF), low defoliation intensity (LDI), high defoliation intensity (HDI), sowing date $(\bullet)$, seedling emergence $(\bullet)$; plant transplant $(\Delta)$, defoliation (x), flowering beginning $(\square)$, presence of immature pods $(\downarrow)$ and crop harvest $(\circ)$. The number under each reference indicates the date.

Table 2. Vegetative and reproductive variables (average \pm SEM) of Lotus tenuis crops defoliated at different flowering stages, in Experiment 1. Crops were defoliated at the beginning of the flowering (DBF), mid-flowering (DMF) or at full flowering (DFF). Crop heights and umbels with flowers, values with different letters are different $(P<0.05)$.

\begin{tabular}{|c|c|c|c|c|c|c|c|}
\hline $\begin{array}{l}\text { Flowering } \\
\text { stages }\end{array}$ & $\begin{array}{c}\text { Date of } \\
\text { defoliation }\end{array}$ & $\begin{array}{c}\text { Control } \\
\text { height }(\mathrm{cm})\end{array}$ & $\begin{array}{l}\text { Crop height } \\
\text { before } \\
\text { defoliation }(\mathrm{cm})\end{array}$ & $\begin{array}{c}\text { Crop height } \\
\text { after } \\
\text { defoliation }(\mathrm{cm})\end{array}$ & $\begin{array}{l}\text { Umbels with } \\
\text { flowers }\left(\mathrm{N} \cdot \mathrm{m}^{-2}\right)^{\mathrm{a}}\end{array}$ & $\begin{array}{l}\text { Vegetation } \\
\text { cover }(\%)^{\mathrm{a}}\end{array}$ & $\begin{array}{c}\text { Yield } \\
\left(\mathrm{kg} \cdot \mathrm{DM} \cdot \mathrm{ha}^{-1}\right)\end{array}$ \\
\hline DBF & 28 Dec. 10 & $27.2 \pm 2.0^{\mathrm{bc}}$ & $26.1 \pm 2.6^{\mathrm{bc}}$ & $17.6 \pm 2.5^{d}$ & $22.0 \pm 7.1^{b}$ & $91.4 \pm 1.3$ & $762 \pm 175$ \\
\hline $\mathrm{DMF}$ & 03 Jan. 11 & $35.7 \pm 0.8^{\mathrm{a}}$ & $35.6 \pm 1.1^{\mathrm{a}}$ & $22.9 \pm 0.6^{\mathrm{bc}}$ & $81.0 \pm 13.6^{b}$ & 100 & $1150 \pm 106$ \\
\hline DFF & 11 Jan. 11 & $36.2 \pm 1.5^{\mathrm{a}}$ & $34.7 \pm 1.7^{\mathrm{a}}$ & $21.6 \pm 1.9^{\text {bd }}$ & $448 \pm 30.3^{\mathrm{a}}$ & 100 & $1182 \pm 84.0$ \\
\hline
\end{tabular}

${ }^{\mathrm{a}}$ Recorded immediately before crop defoliation.

Table 3. Effect of different defoliation intensity in Experiment 2, on crop height, vegetation cover and yield. Treatments were an uncut Control, a low defoliation intensity (LDI) or at high defoliation intensity (HDI). Crop heights with different letters are different $(P<0.05)$.

\begin{tabular}{cccc}
\hline Treatments & Crop height after defoliation $(\mathrm{cm})$ & Vegetation cover $(\%)^{\mathrm{a}}$ & ${\text { Yield }\left(\mathrm{kg} \cdot \mathrm{DM} \cdot \mathrm{ha}{ }^{-1}\right)}^{-}$ \\
\hline Control & $20.9 \pm 0.1^{\mathrm{a}}$ & $87.0 \pm 5.4$ & $995 \pm 163$ \\
LDI & $10.5 \pm 1.6^{\mathrm{b}}$ & $88.0 \pm 2.8$ & $1374 \pm 180$ \\
HDI & $5.8 \pm 0.7^{\mathrm{b}}$ & $87.8 \pm 2.7$ & \\
\hline
\end{tabular}

${ }^{\mathrm{a}}$ Recorded immediately before crop defoliation.

LZ6 colour of $3072 \times 2048$ pixels) camera was positioned vertically $1.0 \mathrm{~m}$ above the top of the plant canopy, perpendicular to the ground and the photos were taken. Two subsamples were set with wire hoops of $0.56 \mathrm{~m}$ diameter, in each plot and identified with three permanent wire stakes. The subsamples areas were photographed until vegetation cover was $100 \%$. The images were analysed using the CobCal software [9].

\subsection{Intercepted Photosynthetically Active Radiation (PAR)}

Ligh interception by the crop canopy was measured at midday in full-sun conditions, using a 1-m long quantum sensor (Cava-Rad). The sensor was placed perpendicular to the rows. Two or four measurements per plot were 
recorded and averaged. Light interception measurements were initiated when crop cover in the Control reached 100\%, on January 3, 2011 in Experiment 1 and on December 27, 2011 in Experiment 2. Intercepted PAR was expressed as percentage using the following formula:

$$
\mathrm{PAR}=100-((\mathrm{I} / \mathrm{Io}) \times 100)
$$

where Io is total PAR above the canopy and I is PAR reaching the soil surface below the canopy.

\subsection{Reproductive Development}

The number of umbels with flowers and pods was determined using a non-destructive method. Permanent marked areas, two of $0.56 \mathrm{~m}$ diameter in Experiment 1 and three of $0.34 \mathrm{~m}$ diameter in Experiment 2, were photographed regularly in each plot. The number of umbels with open flowers and umbels with immature and mature pods were counted in each photograph and averaged.

To assess the accuracy of the digital image in determining the number of reproductive organs, a calibration was conducted in a separate $L$. tenuis plot, growing under the same experimental conditions. Hoops of $0.34 \mathrm{~m}$ diameter were placed randomly and photographed. The areas were harvested and the reproductive organs were counted. The number of reproductive organs estimated from digital images was compared with the counted ones and fitting a simple liniar regression model for umbels with flowers $\left(r^{2}=0.85 ; P<0.0001\right)$ :

$$
\mathrm{N} \mathrm{Fl} \mathrm{H}=2.938+0.904 \times \mathrm{N} \text { Fl E }
$$

and umbels with pods $\left.r^{2}=0.97 ; P<0.0001\right)$ :

$$
\mathrm{N} \mathrm{P} \mathrm{H}=0.532+1.288 \times \text { N P E }
$$

where N Fl H and N P H were the number of umbels with flowers and pods harvested, respectively. N Fl E and N P E were the number of umbels with flowers and pods estimated from digital images, respectively.

Accumulated growing degree-days (AGDD) were used to investigate differences in the development of umbels with flowers and pods:

$$
\mathrm{AGDD}=\sum_{\text {Stage A }}^{\text {Stage } \mathrm{B}}(\mathrm{T})
$$

The AGDD between sowing date in the pots (Stage A) and final harvest (Stage B) was calculated as the sum of the mean daily temperature (T):

$$
\mathrm{T}=[((\mathrm{Tmax}+\mathrm{Tmin}) / 2)-\mathrm{Tb}]
$$

where Tmax and Tmin were the maximum and minimum temperatures, respectively, over the interval from sowing date to final harvest. $\mathrm{Tb}$ is the base temperature of $5^{\circ} \mathrm{C}$, which was assumed to be the same as that determined for Lotus corniculatus [20]. Negative values were not included in the calculation [21].

Pod/flower ratio per umbel was quantified on marked stems. Ten umbels with open flowers per plot were selected randomly and the pedicels tagged with small colour rings. The mature pod number was determined on the same umbels.

\subsection{Final Harvest of Aboveground Biomass}

Final harvest dates of the experiments were according to pod maturation ( $>75 \%$ ) (Figure 1). Plots were cut at 3 $\mathrm{cm}$ above soil level within the $1 \mathrm{~m}^{2}$ central area. Fresh biomass was stored at $4{ }^{\circ} \mathrm{C}$ and all umbels with reproductive organs were removed by hand. Dry weights of vegetative and reproductive biomass were determined. Harvest index (HI) was calculated as the ratio between seed production and total biomass (reproductive plus vegetative components). Seed number per pod was determined from a sample of 30 mature pods selected at random from each plot. Mature pods were hand threshed and the seeds were cleaned, sieved and weighed. Seed mean weight was determined from three samples of 500 seeds per plot. Seed germination was tested by using three samples of 100 seeds per plot following seed testing rules [22].

\subsection{Statistical Analysis}

Data were analysed using analysis of variance (ANOVA). Intercepted PAR, vegetative cover and umbels with 
flowers and pods were analysed by using a repeated-measures procedure. When ANOVA was significant, the means were separated by Fisher's LSD test at the $5 \%$ level of probability. All calculations were performed using Statistica 6.0 software.

\section{Results}

In Experiment 2 L. tenuis was sowed 42 days before that in Experiment 1 (Figure 1). Total plant biomass at the transplant date was higher in Experiment 2 than in Experiment 1. Despite of these differences, in sowing dates and plant biomass, floral initiation was approximately the same calendar days, on December 28, 2010 for Experiment 1 and on December 30, 2011 for Experiment 2, both with a photoperiod of 15.8 hours.

Seed germination was not affected by treatments being $95.0 \% \pm 0.7 \%$ in Experiment 1 and $99.4 \% \pm 0.3 \%$ in Experiment 2. Defoliation delayed pod ripening. Control crops were harvested between five and eight days earlier than defoliated crops (Figure 1). Pod/flower ratio per umbel was unaffected by the treatments, and average $74 \%$ across the two experiments. Plant survival was not affected by defoliation treatments in any of the experiments.

\subsection{Experiment 1. Defoliation at Different Flowering Stages}

Dry matter harvested through DBF treatment was 35\% lower than the produced from DMF and DFF conditions (Table 2). Crop cover was only affected by defoliation at the beginning of the flowering. On 3 January 2011, five days after defoliation, vegetation cover in DBF was $88.0 \% \pm 2.4 \%$, which was lower $(p=0.02)$ than $96.2 \%$ $\pm 0.8 \%$ in Control, DMF and DFF treatments. Nine days after defoliation, vegetation cover of all treatments was $100 \%$. The amount of PAR intercepted by the crops was $93.8 \% \pm 0.7 \%$ and was similar for all treatments during pod production. Results of final harvest of aboveground biomass indicated that defoliation treatments did not affect the vegetative and reproductive variables measured (Table 4). There were less umbels with dehiscent (shattered) pods $(p<0.001)$ in the DFF treatment $(0.83 \% \pm 0.4 \%)$ than in Control, DBF and DMF treatments $(7.5 \% \pm 1.5 \%)$. The number of umbels with immature pods was similar for all treatments $(3 \%)$.

Time $\mathrm{x}$ defoliation treatment interaction effects was significant on flower and pod $(P<0.0001)$. Flowering initiation in all treatments was at $1189^{\circ} \mathrm{C}$ day (Figure 2(a)). Flowering after defoliation was earlier in DBF $\left(1250^{\circ} \mathrm{C}\right.$ day) than in DMF $\left(1400^{\circ} \mathrm{C}\right.$ day) and in DFF $\left(1500^{\circ} \mathrm{C}\right.$ day) conditions (Figure 2(a)). Firstly flower production peaked was in the Control, DBF and DMF treatments $\left(1700^{\circ} \mathrm{C}\right.$ day) and eight days later $\left(1800^{\circ} \mathrm{C}\right.$ day) in DFF plots (Figure 2(a)). Pod initiation was earlier in control $\left(1298^{\circ} \mathrm{C}\right.$ day) than in defoliation conditions

Table 4. Vegetative and reproductive variables determined in Lotus tenuis plants defoliated at different phenological stage of Experiment 1. Treatments were an uncut Control or defoliated at the beginning of the flowering (DBF), mid-flowering (DMF) or at full flowering (DFF). SEM is the standard error of the mean. Treatments within each variable were not different $(P>0.05)$.

\begin{tabular}{|c|c|c|c|c|c|c|c|}
\hline \multirow{2}{*}{ Variables } & \multicolumn{7}{|c|}{ Treatments } \\
\hline & Control & $\mathrm{DBF}$ & $\mathrm{DMF}$ & DFF & Mean & SEM & $P$ \\
\hline Total biomass $\left(\mathrm{kg} \cdot \mathrm{DM} \cdot \mathrm{ha}^{-1}\right)$ & 9088 & 9583 & 9058 & 9026 & 9189 & 132 & 0.855 \\
\hline Vegetative biomass $\left(\mathrm{kg} \cdot \mathrm{DM} \cdot \mathrm{ha}^{-1}\right)$ & 5773 & 6244 & 5864 & 5861 & 5966 & 104 & 0.818 \\
\hline Reproductive $\left(\mathrm{kg} \cdot \mathrm{DM} \cdot \mathrm{ha}^{-1}\right)$ & 3325 & 3274 & 3195 & 2915 & 3177 & 91.5 & 0.501 \\
\hline Empty pods $\left(\mathrm{kg} \cdot \mathrm{DM} \cdot \mathrm{ha}^{-1}\right)$ & 1867 & 1852 & 1800 & 1553 & 1768 & 73.0 & 0.262 \\
\hline Immature pods $\left(\mathrm{kg} \cdot \mathrm{DM} \cdot \mathrm{ha}^{-1}\right)$ & 62.5 & 132 & 95.0 & 115 & 101 & 15.0 & 0.076 \\
\hline Seed yield $\left(\mathrm{kg} \cdot \mathrm{DM} \cdot \mathrm{ha}^{-1}\right)$ & 1393 & 1359 & 1297 & 1244 & 1324 & 32.8 & 0.773 \\
\hline Thousand seeds weight (g) & 1.0020 & 1.0354 & 0.9928 & 0.9838 & 1.0030 & 0.11 & 0.788 \\
\hline Harvest index (\%) & 15.3 & 14.1 & 14.4 & 14.2 & 14.5 & 0.25 & 0.788 \\
\hline Flowers $\left(\mathrm{N} \cdot \mathrm{umbel}^{-1}\right)$ & 5.7 & 5.7 & 5.5 & 5.6 & 5.6 & 0.05 & 0.573 \\
\hline Pods (N·umbel ${ }^{-1}$ ) & 4.0 & 3.9 & 3.8 & 4.4 & 4.0 & 0.12 & 0.066 \\
\hline Seeds $\left(N \cdot p^{-1}\right)$ & 12.9 & 13.8 & 12.5 & 13.8 & 13.3 & 0.33 & 0.446 \\
\hline
\end{tabular}




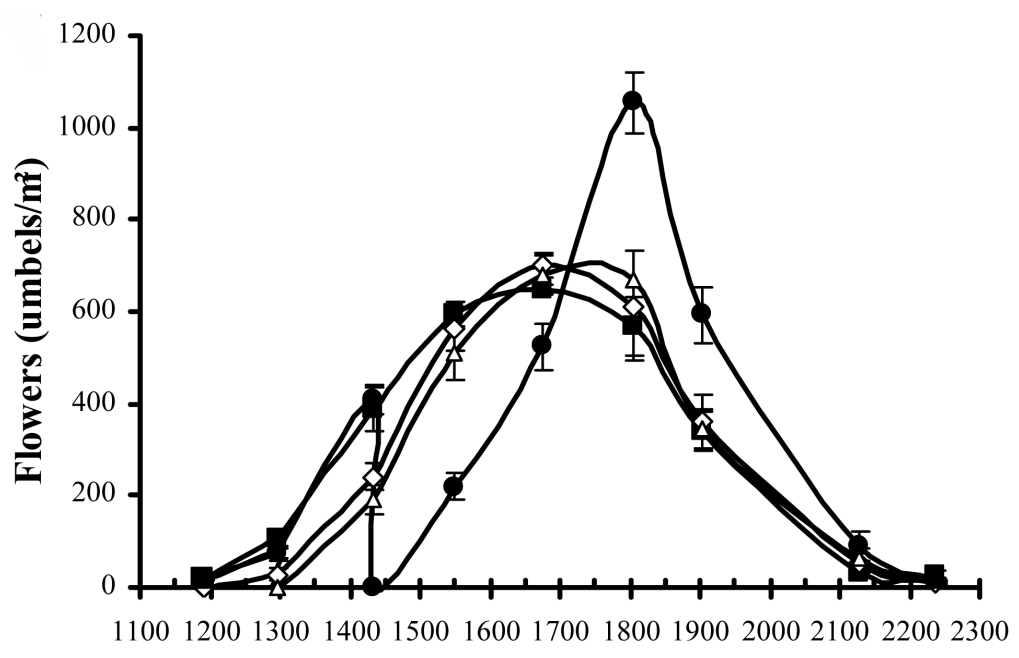

(a)

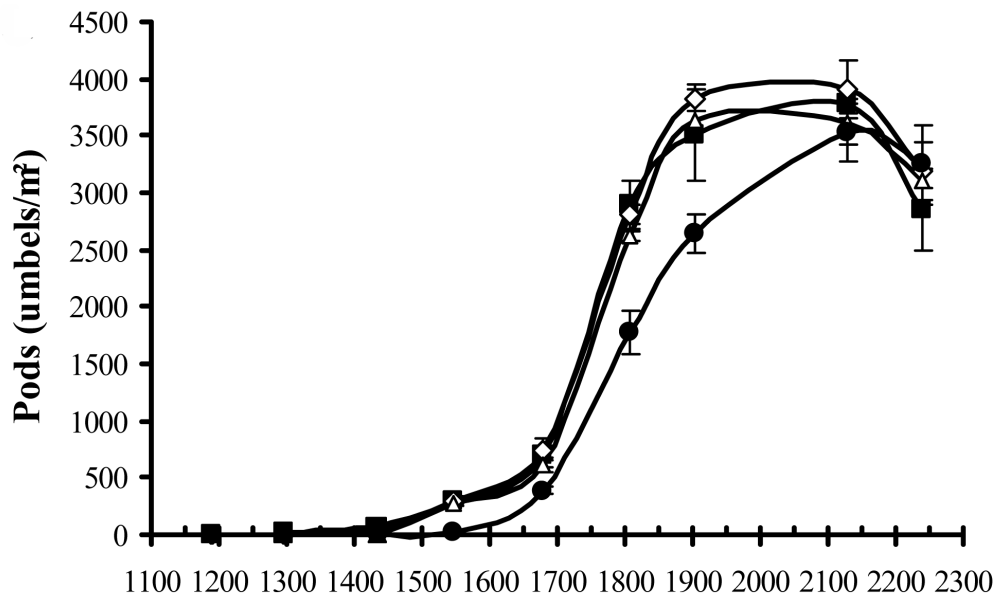

Accumulated growing degree-days $\left({ }^{\circ} \mathrm{C}\right)$

(b)

Figure 2. Dynamic of umbels with flowers (a) and pods (b) in Lotus tenuis crop defoliated at different flowering stage (Experiment 1). The treatments applied were a Control ( $\mathbf{})$, defoliated at the beginning of the flowering $(\diamond)$, defoliated at mid-flowering $(\Delta)$ and defoliated at full flowering $(\bullet)$. Error bars are standard errors of the means (note: some error bars are smaller than the symbol).

( $1433^{\circ} \mathrm{C}$ day). Fifty percent of the umbels with pods were first produced in Control, DBF and DMF on 2 February $2011\left(1750^{\circ} \mathrm{C}\right.$ day) and six days later $\left(1850^{\circ} \mathrm{C}\right.$ day) in DFF plots (Figure 2(b)). Seed yield was not significantly affected by the treatments (Table 4).

\subsection{Experiment 2. Defoliation at Different Intensities}

Dry matter harvested through HDI treatment was 28\% higher than in LDI condition (Table 5). Crop cover $(P=$ 0.043) and PAR interception $(P=0.033)$ differed between treatments when measured 13 days after defoliation (Table 5). Twenty one days after defoliation, vegetation cover was $100 \%$ and PAR interception was not different between treatments. Maximum PAR interception (94.4 \pm 0.7\%) was reached during early pod development.

Defoliation did not affect the production of umbels with flowers and umbels with pods; it only varied with time $(P<0.0001)$. Floral initiation was earlier in control and LDI $\left(1450^{\circ} \mathrm{C}\right.$ day) than in $\mathrm{HDI}\left(1490^{\circ} \mathrm{C}\right.$ day) treatment (Figure 3(a)). High defoliation intensity delaying pod initiation and harvest time (Figure 1). Pod initiation was earlier in Control and LDI $\left(1490^{\circ} \mathrm{C}\right.$ day) than HDI $\left(1609^{\circ} \mathrm{C}\right.$ day) condition (Figure 3(b)). 


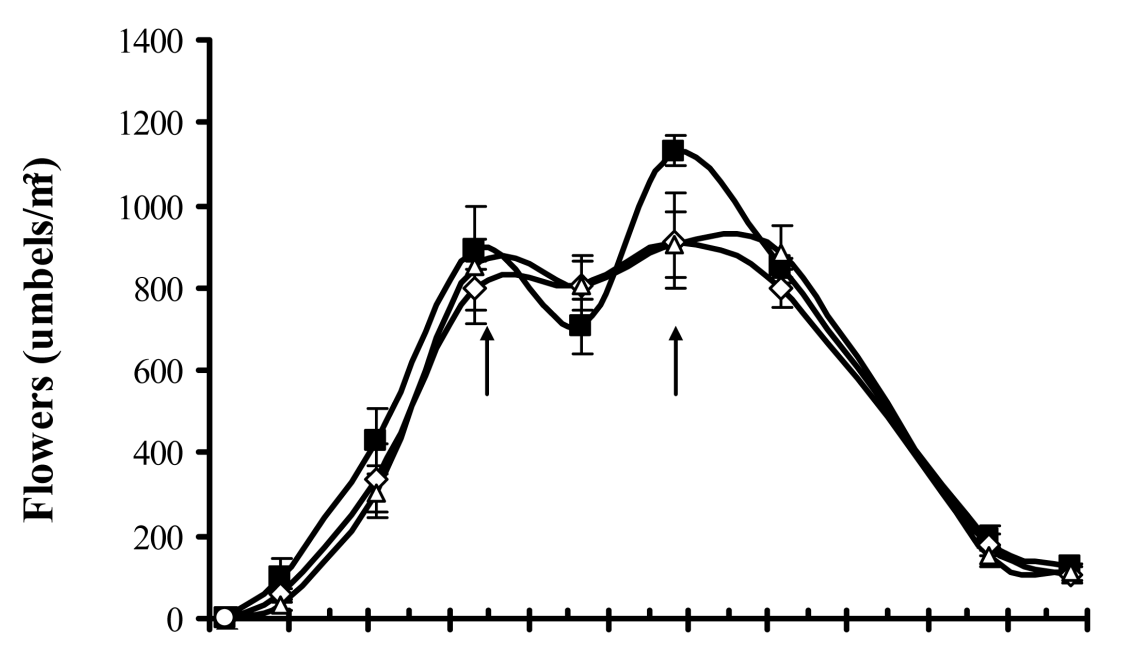

140015001600170018001900200021002200230024002500

(a)

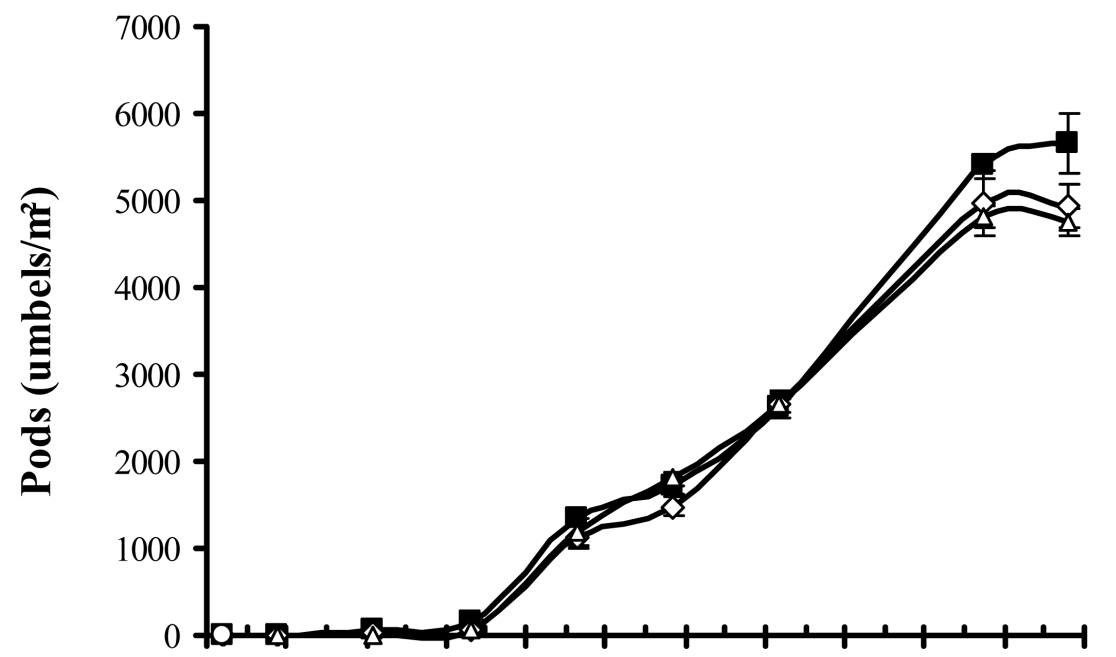

140015001600170018001900200021002200230024002500

\section{Accumulated growing degree-days}

(b)

Figure 3. Dynamic of umbels with (a) flowers and (b) pods in Lotus tenuis crop defoliated at different intensities. Treatments applied were a Control $(\mathbf{\square})$, a low defoliation intensity $(\diamond)$, and a high defoliation intensity $(\Delta)$. Arrows indicate the flowering peaks. Error bars are standard error of the mean (note: some error bars are smaller than the symbol).

Flower production peaked twice and it was more important in the Control than in defoliated treatments (Figure 3(a)). At the end of the experiment, vegetative dry matter harvested from Control and LDI treatment was $5325 \pm 196 \mathrm{~kg} \cdot \mathrm{ha}^{-1}$, which was $27 \%$ higher $(P=0.012)$ than the $4183 \pm 194 \mathrm{~kg} \cdot \mathrm{ha}^{-1}$ produced from HDI (Table 5). Total umbels with mature pods (empty pods) in the Control were similar to LDI, but $12 \%$ higher $(P<$ 0.043) than HDI treatment (Table 5 and Figure 3(b)). However, seed yield (962 $\pm 25.9 \mathrm{~kg} \cdot \mathrm{ha}^{-1}$ ) was similar, regardless of defoliation intensity (Table 5). Maximum umbel with pods was at $2350^{\circ} \mathrm{C}$ day in all treatments (Figure 3(b)). Harvest index from the Control and LDI treatments were lower $(P<0.0108)$ than from the HDI treatment (Table 5). Umbels with immature $\left(641 \pm 51.2 \mathrm{~N} \cdot \mathrm{m}^{-2}\right)$ and dehiscent pods $(17.9 \pm 1.02 \%)$ were unaffected by the treatments (Table 5). Thousand-seed weight was not affected by defoliation intensity (0.9817 \pm $0.0157 \mathrm{~g}$ ) and was similar for all treatments (Table 5). 
Table 5. Vegetative and reproductive variables of Lotus tenuis plants defoliated at different intensities in Experiment 2. Treatments were low (LDI) or at high (HDI) defoliation intensity. Variables within each row with distinct letters are different among treatments $(P<0.05)$. SEM is the standard error of the mean.

\begin{tabular}{|c|c|c|c|c|c|c|}
\hline \multirow{2}{*}{ Variables } & \multicolumn{6}{|c|}{ Treatments } \\
\hline & Control & LDI & HDI & Mean & SEM & $P$ \\
\hline Total biomass $\left(\mathrm{kg} \cdot \mathrm{DM} \cdot \mathrm{ha}^{-1}\right)$ & $8252^{\mathrm{a}}$ & $7774^{\mathrm{a}}$ & $6662^{\mathrm{b}}$ & 7563 & 470 & 0.013 \\
\hline Vegetative biomass $\left(\mathrm{kg} \cdot \mathrm{DM} \cdot \mathrm{ha}^{-1}\right)$ & $5434^{\mathrm{a}}$ & $5214^{\mathrm{a}}$ & $4183^{b}$ & 4944 & 385 & 0.012 \\
\hline Reproductive $\left(\mathrm{kg} \cdot \mathrm{DM} \cdot \mathrm{ha}^{-1}\right)$ & 2818 & 2559 & 2479 & 2618 & 102 & 0.079 \\
\hline Empty pods $\left(\mathrm{kg} \cdot \mathrm{DM} \cdot \mathrm{ha}^{-1}\right)^{\mathrm{a}}$ & $1381^{\mathrm{a}}$ & $1258^{\mathrm{ab}}$ & $1214^{\mathrm{b}}$ & 1284 & 49.9 & 0.043 \\
\hline Immature pod $\left(\mathrm{kg} \cdot \mathrm{DM} \cdot \mathrm{ha}^{-1}\right)$ & $414^{\mathrm{a}}$ & $374^{\mathrm{a}}$ & $296^{\mathrm{a}}$ & 361 & 34.6 & 0.268 \\
\hline Seed yield $\left(\mathrm{kg} \cdot \mathrm{m}^{-2}\right)$ & $1007^{\mathrm{a}}$ & $917^{\mathrm{a}}$ & $961^{\mathrm{a}}$ & 962 & 25.9 & 0.459 \\
\hline 1000 seeds (g) & $1.0064^{\mathrm{a}}$ & $0.9865^{\mathrm{a}}$ & $0.9523^{\mathrm{a}}$ & 0.9817 & 0.0157 & 0.066 \\
\hline Harvest index (\%) & $12.3^{\mathrm{a}}$ & $11.8^{\mathrm{a}}$ & $14.5^{\mathrm{b}}$ & 12.8 & 0.81 & 0.010 \\
\hline Umbels with dehiscent pod (\%) & $16.1^{\mathrm{a}}$ & $19.6^{\mathrm{a}}$ & $18.1^{\mathrm{a}}$ & 17.9 & 1.02 & 0.641 \\
\hline Flowers $\left(\mathrm{N} \cdot \mathrm{umbel}^{-1}\right)$ & $5.3^{\mathrm{a}}$ & $5.3^{\mathrm{a}}$ & $5.8^{\mathrm{b}}$ & 5.7 & 0.15 & 0.036 \\
\hline Pods (N·umbel ${ }^{-1}$ ) & $3.6^{\mathrm{a}}$ & $3.9^{\mathrm{a}}$ & $4.2^{\mathrm{a}}$ & 3.9 & 0.16 & 0.065 \\
\hline Seed $\left(N \cdot \operatorname{pod}^{-1}\right)$ & $12.8^{\mathrm{a}}$ & $12.6^{\mathrm{a}}$ & $14.5^{\mathrm{a}}$ & 13.3 & 0.58 & 0.148 \\
\hline Vegetation cover (\%) & $91^{\mathrm{a}}$ & $92^{\mathrm{a}}$ & $76^{\mathrm{b}}$ & 86 & 5.1 & 0.049 \\
\hline $\operatorname{PAR}(\%)^{\mathrm{c}}$ & $78^{\mathrm{a}}$ & $67^{\mathrm{ab}}$ & $58^{\mathrm{b}}$ & 68 & 5.8 & 0.033 \\
\hline
\end{tabular}

${ }^{\mathrm{a}}$ Mature and without seed after hand threshed. ${ }^{\mathrm{b}}$ Data determined on 23 December 2011, 9 days after defoliation. ${ }^{\mathrm{c}}$ Data determined on 27 December 2011, 13 days after defoliation.

\section{Discussion}

Although the experiments were seeded in different dates and total plant biomass at the transplant date was higher in Experiment 2 than in Experiment 1, floral initiation was on the same calendar days, at the end of December. Temperature and photoperiod influence the rate of crop development and are environmental signs for flower initiation [23]. Time to flowering of different species as Hedysarum coronarium, Onobrychis viciifolia, Pisum sativum, Trifolium alexandrinum, T. resupinatum, Vicia faba, V. sativa and V. villosa [24] and Glycine max cultivars [25] was explained by temperature and photoperiod. In our experiments, Lotus tenuis floral initiation was at different AGDD, $1189^{\circ} \mathrm{C}$ day for Experiment 1 and $1450^{\circ} \mathrm{C}$ day for Experiment 2, but during the same photoperiod, 15.8 hours. Therefore, although temperature is an important factor controlling the rate of plant development, in our work the photoperiod could be more important environmental signal for flower initiation [24]. The photoperiod of $L$. tenuis by flower initiation was consistent with the requirement reported for the flowering of different cultivars of Lotus corniculatus [26].

Lotus tenuis flowering peaked in middle January, which was consistent with the results reported in different Lotus species [5]. When defoliation occurred at flowering, it reduced the duration of pod filling and seed yield [17] [18] [27] [28]. Although L. tenuis defoliation at the full flowering delayed the time until flowering peaked, pod production and seed yield were un-affected. This is likely because of the indeterminate growth habit, phenotypical plasticity and recuperation time after defoliation which favoured the compensatory responses in reproductive and vegetative growth [8] [9]. Lotus tenuis overcame the early differences in crop cover and intercepted PAR resulting from the defoliation treatments imposed. Our results are in agreement with those reported in Glycine max [14], Trifolium repens [29] and L. tenuis [8]. The works showed that defoliation at beginning of flowering or pod production had no significant effect on seed yield and it was attributed to the crop ability to regenerate the canopy during reproductive stage [14]. Final pod number and seed yield can be affected by defoliation if it affects above biomass during flowering period [14] [25]. Vegetative biomass accumulation was lower in HDI than in Control and LDI treatments (Table 5). However, seed yield was not significantly different be- 
tween treatments $\left(962 \mathrm{~kg} \cdot \mathrm{ha}^{-1}\right)$, because it was compensated through an increase in the harvest index which was $12.26 \%$ in Control to $14.44 \%$ in HDI treatment (Table 5). These results are in agreement with those reported in Onobrychis viciaefolia (Fabaceae), where harvest index of the defoliated and undefoliated plants were 26 and $18 \%$, respectively [30].

Low seed harvest index due to seed loss through pod shattering during the reproductive period has been a major problem in some genus of Lotus [5] [10]. The critical point for Lotus spp seed production is to determine the harvest time, this is usually done by using pod colour as an indicator of seed maturity. Since all pods do not reach maturity at the same time, an optimum proportion of immature, mature and shattered pods are required to maximise seed yield through harvest [5] [10]. According to our experiments, flowering can be synchronized through defoliation, as it was reported in Lotus corniculatus crop. The blooming of large numbers of flowers in a short time can be achieved, reducing the number of shattered pods [17]. This information is consistent with the results showed in the Experiment 1; when $L$. tenuis was defoliated at the full flowering the dehiscent pods were lower than in the Control.

Pod production was not limited by the number of flowers. Approximately 74\% of flowers per umbel developed pods. Lotus tenuis reproductive regulation was achieved through the abortion of some flowers without affecting seed size and germination [8] [31]. Plasticity in yield components in response to environmental conditions as plant density and defoliation, triggers a sequence of changes. First, fruit number is reduced. This is followed by a reduction in seed number per fruit and, finally, seed weight may be affected [14] [32] [32]. These results are important because $L$. tenuis seeds are small (approximately $1 \mathrm{mg} \mathrm{seed}^{-1}$ ), and the seedling vigour is related to seed size [34] [35]. However, in previous experiments performed with the same experimental field, $L$. tenuis cultivars under mechanical defoliation at early flowering, had similar seed yields, but thousand-seed weight was lower under defoliation than in the Control treatment [9]. Reduction in thousand-seed weight under defoliation through, clipping or grazing, were also reported in Glycine max [14], Trifolium alexandrinum [15] and in Lotus pedunculatus [18]. Seed size can vary within a plant species if defoliation reduces the availability of assimilates for partitioning during seed fill [14].

\section{Conclusion}

The results of study showed that defoliation did not affect $L$. tenuis plant survival and regrowth capacity, being possible to harvest dry matter without affected the seed yield. Defoliation affected flowers and pods development, but compensatory responses through plant phenotypical plasticity and recuperation time, conferred $L$. tenuis the ability to overcome cutting biomass at different intensities or growing stages. Lotus tenuis defoliation as management tool will be considered in future researches because it is possible to harvest forage and to increase seed yield through a reduction of shattered pods.

\section{Acknowledgements}

We thank María Rosa Desirello and Sara Garfinkel for critical reading of the text and S. Muñoz and J. Giuliano by helped us in the field work. The authors would like to express their gratitude to the referees. This work was supported by the Facultad de Ciencias Agrarias, Universidad Nacional de Mar del Plata-Estación Experimental Agropecuaria Balcarce, Instituto Nacional de Tecnología Agropecuaria. Proyecto 15/A348; AGR 304/10, 15/ A449.

\section{References}

[1] Beuselinck, P.R., Steiner, J.J. and Rim, Y.W. (2003) Morphological Comparison of Progeny Derived from 4x-2x and 4x-4x Hybridizations of Lotus glaber Mill. and L. corniculatus L. Crop Science, 43, 1741-1746.

[2] Blumenthal, M.J. and McGraw, R.L. (1999) Lotus Adaptation, Use and Management. In: Beuselinck, P.R., Ed., Trefoil: The Science and Technology of Lotus, CSSA Special Publication No. 28, CSSA, Madison, 97-119.

[3] Escaray, F.J., Menendez, A.B., Gárriz, A., Pieckenstain, F.L., Estrella, M.J., Castagno, L.N., Carrasco, P., Sanjuán, J. and Ruiz, O.A. (2012) Ecological and Agronomic Importance of the Plant Genus Lotus. Its Application in Grassland Sustainability and the Amelioration of Constrained and Contaminated Soils. Plant Science, 182, 121-133.

[4] Langworthy, A.D., Lane, P.A., Parsons, D. and Hall, E (2013) Forage Quality Characteristics of Lotus tenuis, NarrowLeaf Birdsfoot Trefoil. Proceedings $22^{\text {nd }}$ International Grassland Congress, Sydney, 15-19 September 2013, 682-683.

[5] Sanders, K.J. and Rowarth, J.S. (1995) The Flowering Pattern and Seed Development of Lotus Species. Proceedings 
Agronomy Society of New Zealand, 25, 63-67.

[6] Seaney, R.R. and Henson, P.R. (1970) Birdsfoot Trefoil. Advances in Agronomy, 22, 119-157. http://dx.doi.org/10.1016/S0065-2113(08)60267-9

[7] Clua, A.A., Gimenez, D.O. and Fernandez, L.V. (1997) Increase in Forage Yield in Narrowleaf Birdsfoot Trefoil (Lotus tenuis Waldst \& Kit ex Willd) in a Permanent Pasture with Foliar Applied Gibberellic Acid (GA3), and Phosphorus. Plant Growth Regulation, 21, 223-228.

[8] Vignolio, O.R., Fernández, O.N. and Castaño, J. (2006) Responses of Lotus glaber (Leguminosae) cv. Chajá to Defoliation in Reproductive Stage. Annales Botanici Fennici, 43, 284-287.

[9] Vignolio, O.R., Cambareri, G.S. and Maceira, N.O. (2010) Seed Production of Lotus tenuis (Fabaceae), a Forage Legume: Effects of Row Spacing, Seedling Date, and Plant Defoliation. Crop and Pasture Science, 61, 1027-1035. http://dx.doi.org/10.1071/CP10238

[10] Fairey, D.T. and Smith, R.R. (1999) Seed Production in Birdsfoot Trefoil. In: Beuselinck, P.R., Ed., Trefoil: The Science and Technology of Lotus, CSSA Special Publication No. 28. CSSA, Madison, 145-166.

[11] Malacalza, N.H., Caccavari, M.A., Fagúndez, G. and Lupano, C.E. (2005) Unifloral Honeys of the Province of Buenos Aires, Argentina. Journal of the Science of Food and Agriculture, 85, 1389-1396.

[12] Refi, R.O. and Escuder, C.J. (1998) Nitrogen Fixation by Trifolium repens and Lotus tenuis-Based Pastures in the Flooding Pampa, Argentina. Agronomie, 18, 285-297. http://dx.doi.org/10.1051/agro:19980404

[13] Fan, J., Zhong, H. and Harris, W. (2004) Effects of Cutting at Different Reproductive Development Stages on Aftermath Growth of Red Clover (Trifolium pratense) in a Subtropical Montane Environment. New Zealand Journal of Agricultural Research, 47, 209-217. http://dx.doi.org/10.1080/00288233.2004.9513588

[14] Gregorutti, V.C., Caviglia, O.P. and Saluso, A. (2012) Defoliation Affects Soybean Yield Depending on Time and Level of Light Interception Reduction. Australian Journal of Crop Science, 6, 1166-1171.

[15] Iannucci, A. (2001) Effects of Harvest Management on Growth Dynamics, Forage and Seed Yield in Berseem Clover. European Journal of Agronomy, 14, 303-314. http://dx.doi.org/10.1016/s1161-0301(01)00093-4

[16] Singer, J.W., Malone, R.W., Meek, D.W. and Drake, D. (2004) Predicting Yield Loss in Indeterminate Soybean from Pod Density Using Simulated Damage Studies. Agronomy Journal, 96, 584-589. http://dx.doi.org/10.2134/agronj2004.0584

[17] Formoso, F. (2011) Producción de Semillas de Especies Forrajeras. Serie Técnica 190, INIA, Uruguay, 233 p.

[18] Lowther, W.L., Wedderburn, M.E. and Trainor, K.D. (1992) Reproductive Phenology and Natural Reseeding of “Grasslands Maku” Lotus pedunculatus in Tussock Grassland Environments. New Zealand Journal of Agricultural Research, 35, 157-162. http://dx.doi.org/10.1080/00288233.1992.10417713

[19] Soil Survey Staff-USDA (1999) Soil Taxonomy: A Basic System for Classifying Soils. Agriculture Handbook 436, United States Government Printing Office, Washington DC.

[20] Hur, S.N. and Nelson, C.J. (1985) Temperature Effects on Germination of Birdsfoot Trefoil and Seombadi. Agronomy Journal, 77, 557-560. http://dx.doi.org/10.2134/agronj1985.00021962007700040013x

[21] Teasdale, J.R., Devine T.E., Mosjidis, J.A., Bellinder, R.R. and Beste, C.E. (2004) Growth and Development of Hairy Vetch Cultivars in the Northeastern United States as Influenced by Planting and Harvesting Date. Agronomy Journal, 96, 1266-1271. http://dx.doi.org/10.2134/agronj2004.1266

[22] International Seed Testing Association (1985) International Rules for Seed Testing. Seed Science and Technology, 13, 299-513.

[23] Kinet, J.M. (1993) Environmental, Chemical, and Genetic Control of Flowering. Horticultural Reviews, 15, $279-334$. http://dx.doi.org/10.1002/9780470650547.ch7

[24] Iannucci, A., Terribile, M.R. and Martiniello, P. (2008) Effects of Temperature and Photoperiod of Flowering Time of Forage Legumes in a Mediterranean Environment. Field Crops Research, 106, 156-162. http://dx.doi.org/10.1016/j.fcr.2007.11.005

[25] Egli, D.B. (2005) Flowering, Pod Set and Reproductive Success in Soya Bean. Journal of Agronomy and Crop Science, 191, 283-291. http://dx.doi.org/10.1111/j.1439-037X.2005.00171.x

[26] Steiner, J.J. (2002) Birdsfoot Trefoil Flowering Response to Photoperiod Length. Crop Science, 42, 1709-1718. http://dx.doi.org/10.2135/cropsci2002.1709

[27] Bologna, J.J., Rowarth, J.S., Frase, T.J. and Hill, G.D. (1996) Management of Birdsfoot Trefoil (Lotus corniculatus L.) Pastures for Productivity and Persistence. Proceedings of the Agronomy Society of New Zealand, 26, 17-21.

[28] Clifford, P.T.P. (1986) Effect of Closing Date and Irrigation on Seed Yield (and Some Yield Components) of “Grasslands Kopu” White Clover. New Zealand Journal of Experimental Agriculture, 14, 271-277. 
http://dx.doi.org/10.1080/03015521.1986.10423039

[29] Medeiros, R.B. and Steiner, J.J. (2000) White Clover Seed Production: III. Cultivar Differences under Contrasting Management Practices. Crop Science, 40, 1317-1324. http://dx.doi.org/10.2135/cropsci2000.4051317x

[30] Martiniello, P. and Teixeira da Silva, J.A. (2011) Physiological and Bioagronomical Aspects Involved in Growth and Yield Components of Cultivated Forage Species in Mediterranean Environments: A Review. The European Journal of Plant Science and Biotechnology, 5, 64-98.

[31] Vignolio, O.R., Fernández, O.N. and Maceira, N.O. (2002) Biomass Allocation to Vegetative and Reproductive Organs in Lotus glaber and L. corniculatus (Fabaceae). Australian Journal of Botany, 50, 75-82. http://dx.doi.org/10.1071/BT01012

[32] McGraw, R.L., Beuselinck, P.R. and Ingram, K.T. (1986) Plant Population Density Effects on Seed Yield of Birdsfoot Trefoil. Agronomy Journal, 78, 201-205. http://dx.doi.org/10.2134/agronj1986.00021962007800010040x

[33] Mondal, M.M.A., Kakir, M.S.A., Ismail, M.R. and Ashrafuzzaman, M. (2011) Effect of Defoliation on Growth, Reproductive Characters and Yield in Mungbean [Vigna radiata (L.) Wilczek]. Australian Journal of Crop Science, 5, 987-992.

[34] Rowarth, J.S. and Sanders, K.J. (1996) Relationship Between Seed Quality Test and Field Emergence for Lotus pedunculatus (Cav.), L. corniculatus (L.) and L. tenuis (Willd). Journal of Applied Seed Production, 14, 87-89.

[35] Vignolio, O.R. and Fernández, O.N. (2011) Lotus tenuis Seedling Establishment and Biomass Production in Flooding Pampa Grasslands (Buenos Aires, Argentina). Chilean Journal of Agricultural Research, 71, 96-103. http://dx.doi.org/10.4067/S0718-58392011000100012 